\title{
The approximate calculation of the MgO rich corner of the

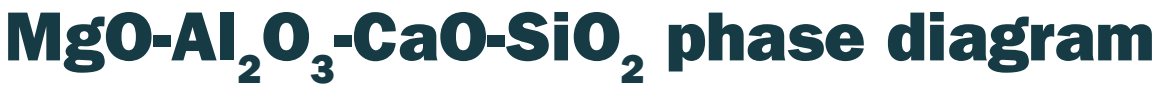 by ESTPHAD method
}

TAmÁs MENDE - Hungarian Academy of Sciences-University of Miskolc, Materials Science Research Group - tamas.mende@uni-miskolc.hu

ANDRÁs ROÓSZ - University of Miskolc, Department of Materials Science, Metal Forming and Nanotechnology = femroosz@uni-miskolc.hu

Érkezett: 2013. 09. 02. - Received: 02. 09. 2013. - http://dx.doi.org/10.14382/epitoanyag-jsbcm.2013.9

\section{Abstract}

The ESTPHAD (Estimation of Phase Diagrams) thermodynamically based phase diagram calculation method was developed by us in the University of Miskolc. The paper shows the writing up by ESTPHAD method of the MgO rich corner of the binary, ternary and quaternary phase diagrams of the $\mathrm{MgO}-\mathrm{Al}_{2} \mathrm{O}_{3}-\mathrm{CaO}-\mathrm{SiO}_{2}$ oxide system. The differences between the calculated data and data from literature are less than $1 \%$ of the liquidus temperature values, which is near equal to the measurement error of the high temperature measuring.

Keywords: equilibrium phase diagram calculation, ESTPHAD method, oxide system

\section{Introduction}

In case of ceramic industries it is very important to know the liquidus temperature of multicomponent oxide system. By using of the ESTPHAD method the liquidus and solidus curves (binary systemí) or surfaces (multicomponent system) of the equilibrium phase diagrams can be calculated by simple equations. The ESTPHAD method has thermodynamic based equations and hierarchical structure. Used to the hierarchical structure, it is possible to approach the ternary liquidus surface (in case of high $\mathrm{MgO}$ concentration) on the basis of the binary phase diagrams even if the ternary system is not known. For the calculations we can use measured or calculated data from literature and with regression analysis we can determine easily the constants of the equations.

\section{Calculation of liquidus temperature}

The equation used in ESTPHAD method (Eq. 1) is based on thermodynamic principles. In equilibrium the partial molar free energy of the phases being in equilibrium are equal. After a long deduction $[1,2]$, the liquidus temperature can be calculated as follows in case of binary A-B system:

$T_{L}=\frac{T_{0}}{1+\sum_{i=1}^{\infty} A(i: 0: 0)\left(c_{B}\right)^{i}}=\frac{T_{0}}{1+F_{A B}\left(c_{B}\right)}$

Where: $\mathrm{T}_{0}$ melting point of pure element $(\mathrm{K}), \mathrm{c}_{\mathrm{B}}$ liquid phase concentration (wt\%), A(i:0:0), $A(0: j: 0)$ and $A(0: 0: k)$ calculated coefficients, $F_{A B}\left(c_{B}\right)$ polynome which belongs to liquidus concentration.

The ESTPHAD algorythm has hierarchical structur, which means that we are able to use the calculated polynomes of binary systems (created in case of A-B and A-C systems) to approximate the ternary A-B-Cliquidus temperature. The results would be more precise used the $\Delta \mathrm{F}_{\mathrm{ABC}}$ function determined from the measured or calculated ternary equilibrium phase diagram (Eq.2.).
$T_{L}=\frac{T_{0}}{1+F_{A B}\left(c_{B}\right)+F_{A C}\left(c_{C}\right)+\Delta F_{A B C}\left(c_{B} ; c_{C}\right)}$

The $\Delta \mathrm{F}_{\mathrm{ABC}}$ function includes mixed products of the concentrations of the components with sufficient powers:

$\Delta F_{A B C}(c)=A(1 ; 1 ; 0) \cdot\left(c_{B}\right) \cdot\left(c_{C}\right)+A(2 ; 1 ; 0) \cdot\left(c_{B}\right)^{2} \cdot\left(c_{C}\right)+A(1 ; 2 ; 0) \cdot\left(c_{B}\right) \cdot\left(c_{C}\right)^{2}+\ldots$

$=\sum_{i=1-} A(i ; j) \cdot\left(c_{B}\right)^{i} \cdot\left(c_{C}\right)^{j}$

The calculation of the liquidus temperature of quaternary system and the FABCD function can be set up by the aforementioned hierarchical way (Eq.4, Eq.5):

$T_{L}=\frac{T_{0}}{1+F_{A B}+F_{A C}+F_{A D}+\Delta F_{A B C}+\Delta F_{A B D}+\Delta F_{A C D}+\Delta F_{A B C D}\left(c_{B} ; c_{C} ; c_{D}\right)}$

$\Delta F_{A B C D}(c)=A(1 ; 1 ; 1) \cdot\left(c_{B}\right) \cdot\left(c_{C}\right) \cdot\left(c_{D}\right)+A(2 ; 1 ; 1) \cdot\left(c_{B}\right)^{2} \cdot\left(c_{C}\right) \cdot\left(c_{D}\right)+\ldots=$

$=\sum_{i, j, k=1-\ldots} A(i ; j ; k) \cdot\left(c_{B}\right)^{i} \cdot\left(c_{C}\right)^{j} \cdot\left(c_{D}\right)^{k}$

\section{Results}

The liquidus curves of the binary phase diagrams can be calculated with $\pm 5 \mathrm{~K}$ variances (which is less than $0,3 \%$ of the liquidus temperature) by the ESTPHAD method. Due to the hierarchical structure of the ESTPHAD method, the liquidus surfaces of the ternary phase diagrams can be approximate with $\pm 25 \mathrm{~K}$ difference (less than $1 \%$ ), the quaternary liquidus temperature (above $80 \mathrm{wt} \% \mathrm{MgO}$ content) $\pm 25 \mathrm{~K}$ difference (less than 1\%). On the following figures can be found the digitalized (which were used as base data for our calculations) and calculated liquidus curves and surfaces.

By using our equations and the following calculated coefficients (Table 1. to 3.) the liquidus temperature can be calculated easily. The $\mathrm{T}_{0}$ initial value in Eq. (1) to (4) is equal to $3083 \mathrm{~K}$. 


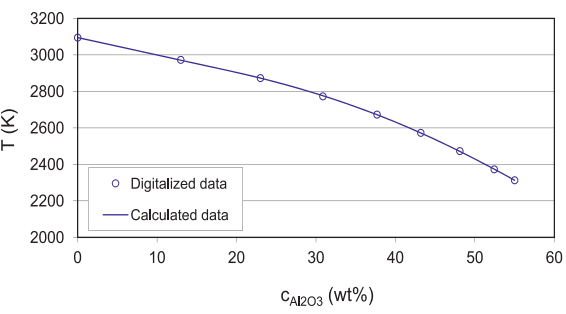

Fig. 1. The digitalized [4] and calculated liquidus curves of $\mathrm{MgO}$ phase in case of $\mathrm{MgO}-\mathrm{Al}_{2} \mathrm{O}_{3}$ phase diagram

1. ábra Az MgO fázis digitalizált [4] és számított likvidusz vonala $\mathrm{MgO}-\mathrm{Al}_{2} \mathrm{O}_{3}$ fázisdiagramban

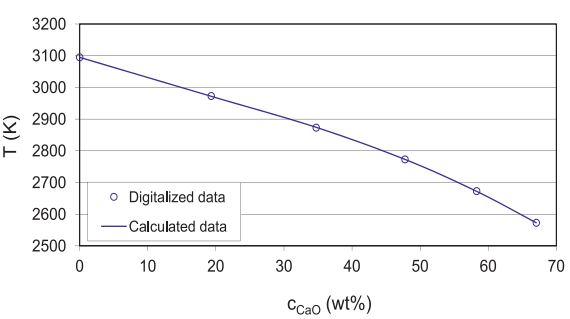

Fig. 2. The digitalized and calculated liquidus curves of $\mathrm{MgO}$ phase in case of $\mathrm{MgO}-\mathrm{CaO}$ phase diagram [4].

2. ábra Az MgO fázis digitalizált és számított likvidusz vonala $\mathrm{MgO}-\mathrm{CaO}$ fázisdiagramban [4]

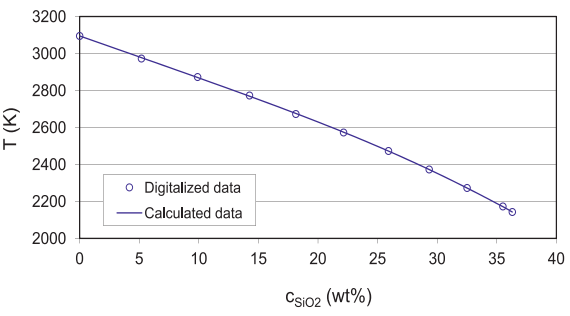

Fig. 3. The digitalized and calculated liquidus curves of $\mathrm{MgO}$ phase in case of $\mathrm{MgO}-\mathrm{SiO}$, phase diagram [3].

3. ábra Az MgO fázis digitalizált és számított likvidusz vonala $\mathrm{MgO}-\mathrm{SiO}_{2}$ fázisdiagramban [3]

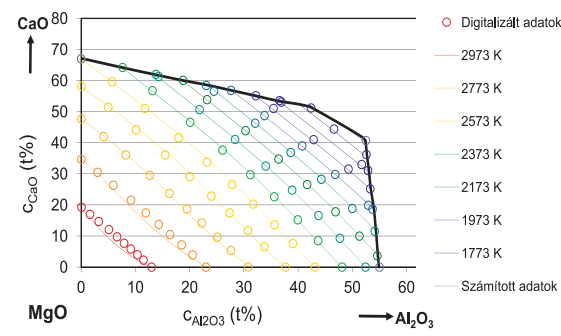

Fig. 4. The digitalized and calculated liquidus surface of $\mathrm{MgO}$ phase in case of $\mathrm{MgO}-\mathrm{Al}_{2} \mathrm{O}_{3}-\mathrm{CaO}$ phase diagram [4]

4. ábra Az MgO fázis digitalizált és számított likvidusz felülete $\mathrm{MgO}-\mathrm{Al}_{2} \mathrm{O}_{3}-\mathrm{CaO}$ fázisdiagramban [4]

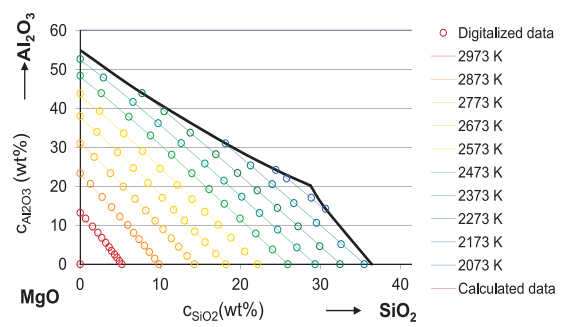

Fig. 5. The digitalized and calculated liquidus surface of $\mathrm{MgO}$ phase in case of $\mathrm{MgO}-\mathrm{Al}_{2} \mathrm{O}_{3}-\mathrm{SiO}_{2}$ phase diagram [3]

5. ábra Az MgO fázis digitalizált és számított likvidusz felülete $\mathrm{MgO}-\mathrm{Al}_{2} \mathrm{O}_{3}-\mathrm{SiO}_{2}$ fázisdiagramban [3]

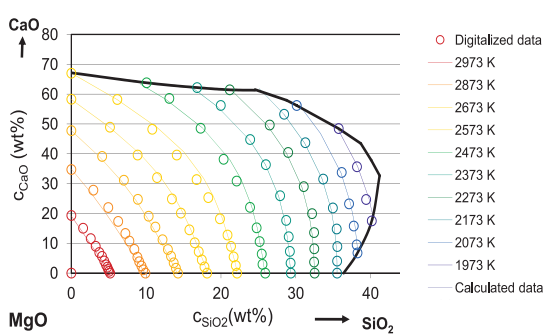

Fig. 6. The digitalized and calculated liquidus surface of $\mathrm{MgO}$ phase in case of $\mathrm{MgO}-\mathrm{CaO}-\mathrm{SiO}$, phase diagram [3].

6. ábra Az MgO fázis digitalizált és számított likvidusz felülete $\mathrm{MgO}-\mathrm{CaO}-\mathrm{SiO}_{2}$ fázisdiagramban [3]

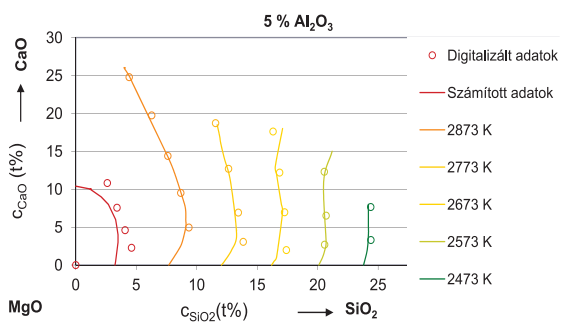

Fig. 7. The digitalized and calculated liquidus surface of $\mathrm{MgO}$ phase in case of $\mathrm{MgO}-\mathrm{CaO}$ $\mathrm{SiO}$ phase diagram and $5 \% \mathrm{Al}_{2} \mathrm{O}_{3}$ section of quaternary system [3].

7. ábra $\mathrm{Az} M \mathrm{MgO}$ fázis digitalizált és számított likvidusz felülete $\mathrm{MgO}-\mathrm{CaO}-\mathrm{SiO}$ fázisdiagramban és a négyfázisú rendszer $5 \% \mathrm{Al}_{2} \mathrm{O}_{3}$ metszete [3]

Ref.:

Tamás Mende - András Roósz: The approximate calculation of the $\mathrm{MgO}$ rich corner of the $\mathrm{MgO}$ $\mathrm{Al}_{2} \mathrm{O}_{3}-\mathrm{CaO}-\mathrm{SiO}_{2}$ phase diagram by ESTPHAD method Építőanyag, 65. évf. 2. szám (2013), 42-43. p. http://dx.doi.org/10.14382/epitoanyag-jsbcm.2013.9

\section{A MgO- $\mathrm{Al}_{2} \mathrm{O}_{3}-\mathrm{CaO}-\mathrm{SiO}_{2}$ fázisdiagram MgO-ban dús sarkának} közelítő számítása ESTPHAD módszerrel

A kerámiaipari vállalatok számára rendkívül fontos a többalkotós oxid-rendszerek likvidusz hőmérsékletének minél pontosabb ismerete. Az ESTPHAD (Estimation of Phase Diagrams - Fázisdiagramok közelítô számítása) módszerrel két- és többalkotós rendszerek (legyen szó fémes vagy oxid) fázisainak likvidusz hômérséklete számítható egy egyszerú egyenlet felhasználásával. Az ESTPHAD algoritmusát termodinamikai egyenletekből levezetve hierarchikus módon építettük fel annak érdekében, hogy többalkotós rendszerek számítására is lehetôség nyíljon. A számítások során szakirodalomból származó egyensúlyi fázisdiagramokat használtunk és regressziós analízissel határoztuk meg az ESTPHAD egyenlet paramétereit.

Kulcsszavak: egyensúlyi fázisdiagram számítás, ESTPHAD módszer, oxid-rendszer 